\title{
Being a management accountant in a shared services centre
}

\author{
Lauri Lepistö $^{a *}$, Justyna Dobroszek ${ }^{b}$,Sinikka Moilanen ${ }^{c}$ Ewelina Zarzycka ${ }^{b}$
}

*Corresponding author

${ }^{a}$ Turku School of Economics, University of Turku, Pori Unit, P.O. Box 170, FI-28101 Pori, Finland

${ }^{b}$ Faculty of Management, University of Lodz, Jana Matejki 22/26, 90-237 Łódź, Poland

${ }^{c}$ Oulu Business School, University of Oulu, P.O. Box 4600, FI-90014 University of Oulu, Finland

\begin{abstract}
Purpose: The purpose of this study is to improve understanding of the work of management accountants in the context of a shared services centre.

Design/Methodology/Approach: A single case study method is employed and data are collected via semi-structured interviews and internal documents. The empirical materials are analysed from the theoretical perspective of dirty work, incorporating aspects from practice theory.

Findings: Findings suggest that management accountants working in a shared services centre develop their occupational esteem by refocusing and reframing strategies. Through these strategies, management accountants can decrease the perceived 'dirtiness' associated with their work.

Originality/value: The study sheds light on the under-researched topic of management accountants' work within a shared services centre. Moreover, it offers the metaphor of liminal work to characterise how management accountants develop their occupational esteem in circumstances where gaining efficiency is the main objective.

Keywords: Case study, dirty work, management accountants, management accounting, shared
\end{abstract} services 


\section{Introduction}

The purpose of this study is to improve understanding of the work of management accountants in the context of a shared services centre. In the recent years, shared services centres have become an increasingly popular choice for organising accounting processes (Oliveira and Clegg, 2015; Seal and Herbert, 2013; Lindvall and Iveroth, 2011). Their popularity is at least partly explained by the advancements in the field of information technology (Oliveira and Clegg, 2015; Bhimani and Willcocks, 2014), and companies' inclination towards cost savings, efficiency improvements and organisational transformation (Raudla and Tammel, 2015; Harritz, 2016). Recent literature portrays shared services centres as a complex social and organisational arrangement. Work conducted in a shared services centre requires esoteric and procedural knowledge (Rothwell et al., 2011) as it is performed in a highly technological environment (Lindvall and Iveroth, 2011) However, it appears that this kind of work enjoys a somewhat unflattering reputation and prejudice (Seal and Herbert, 2013). It is considered as highly scripted and monitored, resulting in a high degree of employee turnover (Howcroft and Richardson, 2012). Thus far, few studies have explicitly focused on the work of accountants in shared services centres (Herbert and Seal, 2012). This is a glaring gap because their work, even though clerical (c.f. Cooper and Taylor, 2000) and less prestigious (c.f. Morales and Lambert, 2013), is critical to organisational performance (Seal and Herbert, 2013).

This paper examines the work of management accountants in the context of a shared services centre from the theoretical perspective of dirty work, incorporating aspects from practice theory (see Ahrens and Chapman, 2007; Akroyd and Maguire, 2011). The concept of dirty work was introduced by Hughes (1958) to characterise tasks that are often considered disgusting, degrading or otherwise 
shameful in society. However, the literature suggests that people associated with dirty work mostly are able to form a positive occupational esteem. Occupational esteem can be defined as a positive sense of self and a belief that one's work is valuable and worthy (Ashforth and Kreiner, 1999). The recent study by Morales and Lambert (2013) illustrates that management accountants may also experience dirty work, and thus they make a distinction between 'clean' and 'unclean' tasks. Their study evidences how the experience of dirty work has linkages to occupational aspirations among management accountants. Through role transition, it may be possible to move away from dirty tasks to clean ones, and consequently, increase one's occupational esteem in organisation-specific circumstances. This study investigates the practices of management accountants, and the linkages between dirty work and occupational esteem in the context of shared services through the following research questions:

1) How do management accountants create a sense of occupational esteem working in a shared services centre?

2) How does the technology-focused nature of management accounting work in a shared services centre affect the occupational esteem of management accountants?

As a case study, this study focuses on a management accounting department in a large outsourcing services company (previously, a shared services centre). Previous research suggests that shared services centres draw on 'scientific management' practices wherein accounting processes are reduced to increasingly technical activities (Seal and Herbert, 2013). Thus, accountants' roles are therefore perceived as narrower and more programmed than those in a client organisation (Herbert and Seal, 2012; Rothwell et al., 2011). The study contributes to the extant research in following ways. It builds on Morales and Lambert's (2013) elaboration of dirty and clean work by using the metaphor of 'liminal' work. This metaphor illustrates how management accountants encounter instability and uncertainty, as standardisation and automation influence their occupational orientation. The study's findings suggest that management accountants create occupational esteem through 'refocusing' and 
'reframing' strategies - of which the latter seems to have transformative potential. Finally, the study evidences how the provision of accounting within a shared services centre is moving towards offering standardisation and automation services (Bhimani and Willcocks, 2014; see also Bhimani, 2003).

The following section presents the theoretical perspective of the study. This is followed by the methodology section. The fourth section is devoted to empirical analysis, and the paper ends with a discussion and conclusions.

\section{Theoretical perspective}

The concept of dirty work is linked to the process of moral division of labour in which tasks and occupations are divided into prestigious and less prestigious ones according to their symbolic connotation (Hughes, 1958). Typically, dirty work is divided into three categories (Ashforth et al., 2007; Ashforth and Kreiner, 2014). At a physical level, tasks can be considered as dirty if they are dangerous, disgusting, burdensome or stressful (e.g. miners). At a social level, work can be perceived as dirty, if it, for instance, includes servile interactions (e.g. call-centre workers). Dirty work can also have a moral taint if the work involves dubious or questionable features (e.g. fortune tellers).

Almost every occupation or profession involves some degree of dirty work, although it usually refers to mechanical tasks performed by relatively unskilled labour. Dirtiness varies in terms of breadth and depth (Kreiner et al., 2006). While some occupations are stigmatised, in some occupations, only specific tasks may contain the potential dirtiness. In light of this, it can be argued that dirty work has both spatial and temporal characteristics. As evidence, accountants in shared services centres can face a pervasive stigma as these organisational arrangements are mostly devoted to managing transactional processes (Rothwell et al., 2011; Herbert and Seal, 2012). According to Morales and Lambert (2013), management accounting could be seen as work in which management accountants have to balance their occupational aspirations and organisational realms, which are mostly regulated by people from upper echelons. Similar observations have been made about 
management consultants. Management consulting can appear as a challenging, increasingly liminal, experience because of the unstable space between a consultant and client (Czarniawska and Mazza, 2003; see also Kornberger et al., 2011). According to Czarniawska and Mazza (2003, p. 267), liminality refers to increasingly unstructured conditions where the usual practice and normal order become suspended and replaced by new contents and features. In this light, the liminality can be characterised as transition and transformation during which the individual may feel disorientation and confusion (Kornberger et al., 2011, p. 517). Sometimes, it is experienced as 'both unsettling and creative' (Sturdy et al., 2006, p. 929).

Despite some empirical studies on the effects of dirty work on employees' well-being (e.g. Baran et al., 2016), the literature suggests that dirty work is a manageable phenomenon (Kreiner et al., 2016). Organisational culture is particularly important in case of dirty work. Asforth and Kreiner (1999) argue that employees associated with dirty work typically have high occupational esteem and a strong work ethos, despite public disregard. Through organisational culture, practices and activities become rationalised and eventually naturalised in a workplace (Kunda, 1992). Thus, workplaces with potential for dirty work can be characterised as 'social cocoons', where employees, through their shared work, develop affinity and a sense of belonging with each other and with the organisation (Jenkins and Delbridge, 2016, p. 16).

Researchers have identified a plethora of ways through which unusual work can be seen as usual and, most importantly, in a positive light. Arguably, the most important route appears to be 'occupational ideologies', through which the dirty work is eventually neutralised (Ashforth and Kreiner, 1999). Occupational ideologies can be applied in different ways (Ashforth and Kreiner, 1999). One way is refocusing - shifting attention from the stigmatised aspects of work to nonstigmatised aspects. The greater the proportion of stigmatised aspects in work, the more refocusing is needed (Kreiner et al., 2006, p. 627). Refocusing overlooks stigmatised attributes of work, which may require certain individual calibration through which the amount and nature of dirty work is 
assessed. Another way is reframing, in which work is framed in a new way to form new, positive meaning or value. However, it is noteworthy that the identified ways through which individuals may maintain positive occupational esteem in conditions of dirty work are inherently mutually inclusive (c.f. Ashforth and Kreiner, 1999; Kreiner et al., 2006; Ashforth and Kreiner, 2014).

Dirty work theorists seem to treat dirty work as a phenomenon that can be managed by adjusting the individual's attitude and orientation towards the stigma. Morales and Lambert (2013) further the discussion by focusing on the designation of dirty work. Conceptually, they divide work performed by management accountants into three categories. 'Clean' work refers to work that is in line with management accountants' occupational aspirations. 'Unclean' work refers to tasks that are clearly in contrast with the desired occupational orientation of management accountants (e.g. correcting errors in data). Finally, 'polluted' work refers to situations in which a task or activity is comparable to the occupational aspiration of a group but nevertheless results in degrading results (e.g. ignorance in board meetings). Thus, individuals' aspirations to extend their occupational orientation are not always successful, even if role transitions usually seem crucial to 'escape' tainted work (Morales and Lambert, 2013).

In addition to Morales and Lambert (2013), some other scholars have implicitly shed light on the shameful aspects prevalent in accounting. Cooper and Taylor (2000) illustrate how relatively lowpaid clerical accountants face deskilling. Tasks requiring specific skills and individual judgement are disappearing as an outcome of advancement of information technology. Hence, clerical accounting increasingly requires balancing repetitive tasks and automation. In a similar vein, it has been argued that shared services are hollowing out a 'professional space' for involvement in business support functions (Rothwell et al., 2011), as accounting roles become more specialised (Seal and Herbert, 2013).

Dirty work literature (Ashforth et al., 2007) typically pays attention to occupational-level considerations, while side-lining individual-level analysis. As a result, the meaning of work in 
relation to dirty work is often implicitly expressed in this area of inquiry. Thus, the present literature review is complemented by incorporating aspects from practice theory. In the recent years, practice theory has gained increasing attention among researchers of management accounting (Ahrens and Chapman, 2007; Whittington, 2011; Akroyd and Maguire, 2011). Practice theory draws on a variety of theoretical sources (Geiger, 2009). It views management accounting as a skilful practical activity that is involved in the production of social order in organisations (Ahrens and Chapman, 2007). In light of this, practices are individual accomplishments performed on a regular basis, which result from the acquisition and application of knowledge (Ahrens, 2009; Stern, 2003). According to Stern (2003), practice theory pays close attention to practices in particular contexts. Practices are both enabled and restricted by collective practice (Geiger, 2009). Practice theorists take practice as a fundamental category and a point of departure in social analysis (Stern, 2003, p. 185). Whittington (2011) points out that practice is something that practitioners do, and not a property owned by an organisation. From this view, accounting can be seen as practice, which is not reducible to normative definitions. Thus, management accounting could be perceived as practice that is forged through individual and collective action in organisation-specific circumstances (Ahrens and Chapman, 2007). This kind of stance views management accounting as a mundane and everyday activity in which shared norms and understandings play a crucial role (Ahrens, 2009). Hence, in practice-based analyses, a researcher's commitment to social practices is of importance (Whittington, 2011, p. 185).

It can be argued that practice theory has a few features in common with the dirty work theory. Practice theory has a positive ontology as individuals are seen to do their best with what they have (Whittington, 2011, p. 184). It also pays attention to individual struggles. Practices result from aspirations and problems of social groups (Ahrens and Chapman, 2007, p. 3), as individuals cope with everyday pressures through improvisation and negotiation (Whittington, 2011, p. 183). Moreover, practice theory emphasises skilful proficiency of individuals. According to Ahrens (2009, p. 43), practice is manifested through diverse technologies which contain both social and material 
aspects. Finally, it recognises mutual constitution of individual and organisational intent - individual activities shape and are shaped by collective practice (Ahrens and Chapman, 2007).

In sum, it could be argued that the concept of dirty work supplemented by insights from practice theory offers tremendous potential to investigate the characteristics of management accountants' work in a specialised site that primarily handles the non-core elements of accounting (Cooper and Taylor, 2000). The recent studies illustrate that the routine (Ahrens, 2009, p. 31) and possibly humble (Morales and Lambert, 2013, p. 432) aspects of organisational activities are worthy of academic analysis. Moreover, the study is a response to the call of Kreiner et al. (2006), who argue that investigations of dirty work should focus on localised definitions. For this reason, this study analyses how people associated with dirty work manage the taint in the domain, which extends to beyond the most obvious spaces.

\section{Methodology}

The study follows the qualitative research methodology seen through the lens of dirty work theory (Ashforth and Kreiner, 1999; Morales and Lambert, 2013) and practice theory (Ahrens and Chapman, 2007; Akroyd and Maguire, 2011; Whittington, 2011). It employs a single case study in response to calls for investigations of dirty work at an individual level, such as in the case of Kreiner et al. (2006), and the experiences of accountants in the context of shared service work described in Herbert and Seal (2012). In particular, this study subscribes to explanatory case-based research, in which theory is used to understand, interpret and explain a specific phenomenon (Scapens, 1990, p. 265). Thus, the role of theory is to offer a theoretical lens and vocabulary for the analysis of observed phenomenon (Lukka and Vinnari, 2014, p. 1312).

The study was conducted in central eastern Europe. The organisation being studied, referred to as 'Outco', was established as a shared services centre in the early 2000s to provide corporate support services to its global parent company. As a result, the parent company's transactional functions and 
processes related to accounting were transferred to the centre. To mimic the typology of Raudla and Tammel (2015), the creation of the shared services centre can be seen as a 'big bang' in which the centre was created during a short period of time. The specific geographical location of the study has been anonymised to preserve the confidentiality of the organisation. In the mid-2000s, the services centre was sold to a world-class outsourcing company located in India. After the acquisition, the services centre experienced incremental growth, during which it began to extend its services and client base. Thus, the shared services centre evolved into a commercial outsourcing company, part of a huge global network of delivery centres belonging to its Indian parent company. Since the acquisition, Outco has operated as an outsourcing company, attempting to attract new customers, while the original parent—-the global company—remains its key client.

Today, Outco employs more than one thousand accounting and finance professionals on site. Its management accounting department represents the most 'advanced' or 'high-end' (to use the company's own characterisations) services of the centre. The department employs over 100 accountants and is responsible for delivering management accounting services that have been transferred from the client. These management accounting services include managerial reporting, budgeting, transfer pricing and performance evaluation. More than 700 entities are to be reported and over 7000 reports are prepared each month. However, it is noteworthy that the management accounting department has only one client — the global company — who previously owned the centre.

This organisation was selected as the case for two reasons. First, the case organisation can be characterised as an increasingly established centre, given that studies on accounting as part of shared services often focus on design or implementation issues (Raudla and Tammel, 2015). Second, the case organisation is particularly suitable as one of its departments focuses on the development of management accounting services, which can be increasingly considered as a 'high-end' service, unlike most services centres that are increasingly devoted to transactional processes (Herbert and Seal, 2012; Howcroft and Richardson, 2012). 
Primary empirical data were collected in the spring of 2016 and summer of 2017. In January 2016, Outco organised a workshop with the research team to discuss the practices and challenges of outsourcing management accounting. Over the course of the research project, 23 interviews were conducted (see Appendix). The respondents comprised employees performing various tasks and ranged from junior- to increasingly senior-level positions in the management accounting department, as well as the unit's HR manager. A semi-structured interview guide was used for the interviews. Standard questions were used to structure the interviews, but ad hoc questions were also posed to understand the informants' explanations and meanings. In total, 22 Outco employees were interviewed. In most cases, two researchers were present at each interview. After each interview session, the recording was transcribed verbatim and then translated. To validate the researchers' interpretations and the most essential facts, a research report was given to the managers of the management accounting department. To avoid biases in the interview materials, the researchers interviewed three employees from the client's side as well (see Appendix). During the fieldwork, 28 job advertisements placed by Outco were also collected to improve the understanding on the skills and requirements that characterise the work of a management accountant in the context of the study. In addition, some internal presentation materials provided by Outco were used to assist in the analysis.

The analysis was conducted in the following stages. To begin with, each member of the research team read the material independently. Next, common underlying themes through which the management accountants interpret and experience their work were identified by the first author, using the transcribed interviews. Next, the entire research team analysed whether these themes were discussed in a positive or negative light via excerpts of the interview text. Finally, the researchers began to understand how management accountants see their work in conditions of dirty work.

\section{Empirical analysis}

\subsection{Management accountants and the experience of dirty work}


According to Hughes (1958, p. 49), analyses of occupations comprising dirty work should begin with the job contents. As the comments below show, the management accountant's main task is to prepare various managerial reports on a regular basis:

'I prepare the forecast based on data provided by the client. He manually downloads the data from their system and sends it to me and I prepare the report. The report contains a forecast of sales during each month and annually as well as a forecast of inventories. Then I also use this data to calculate variances. I do report, but my client analyses it and uses it, and it is their responsibility. I do everything in accordance with instructions. I can comment that some numbers seem strange to me, but I cannot correct or change them. You know, I have a keen eye for numbers because of my experience in preparing so many reports.' (Mr D, Management Accounting Specialist)

'I have two areas, supply chain reporting and reporting for factories. The latter is only monthly reporting. For supply chain, I prepare different reports, sometimes I have [to do] a couple of them in one day. For example on Monday, I have many reports, so I start earlier. I switch on the computer, download data, and launch macros to elaborate those data. In meanwhile I can take coffee because macro takes some time.' (Ms A, Process Manager)

The recipients of the reports are usually the client's management accountants, responsible for further analysis and interpretation, as well as regional and divisional managers. Typically, the reports draw on a spreadsheet application, whose data is retrieved from the client's database. Since the management accounting department produces hundreds of reports every month, it is not uncommon for a single management accountant to produce more than one hundred reports in a month, if he is able to utilise similar reporting templates. In addition to regular reporting, management accountants are in charge of the maintenance and development of the extant reporting templates. Moreover, specific ad hoc tasks assigned by the client occasionally interrupt the commonplace reporting activities.

'SSC is okay as an employer, but I would like to also see something different [...] outsourcing is connected with some restrictions and simplifications. Those processes are repeating. You stay in front of a PC or laptop all the time, and the reports are prepared with some frequency [...]' (Mr A, Process Executive)

In line with the observation of Hughes (1958, p. 51), people associated with dirty work speak frankly about its stigmatised features. Employees openly acknowledge that Outco appears to be a unique work environment for a management accountant. They realise that a shared services centre 
established for the organisation of accounting activities has a somewhat pejorative connotation in the eyes of the public. As the centre was previously a plain shared services centre, to the employees, the organisational context appears both as a service centre and an outsourcing company, as suggested by the excerpt above. Employees seem to use the terms interchangeably. The term 'shared services centre' is used when the centre is seen as a provider of somewhat simple and stable services to its sole client. The term 'outsourcing' is used in the context of its more recent, increasingly proactive and commercially oriented attitude towards accounting services.

The empirical material includes explicit references and expressions related to dirty work. In certain quotations, expressions such as 'dirty work' or 'donkey work' are used to describe the most humble aspects of the work. Although the job of a management accountant can be seen as an information technology-enabled service, delivered from a modern office complex, it could be argued that it also involves the typical dimensions of dirty work (Hughes, 1958; Ashforth and Kreiner, 1999), which are used to characterise manual work. At a physical level, being a management accountant is perceived as dirty work as it often causes considerable stress. With its regular closure and reporting tasks, the work is physically burdening because of the strict time constraints. The department's policy at the studied organisation is to strive for total quality in reporting, where errors and delays should be zero. Thus, standard reporting activities in which a management accountant prepares reports with a similar structure for different markets or divisions require considerable caution and accuracy. An employee summarises it as follows:

'Earlier, consolidating the budgets of departments did not constitute a problem. It was not important whether a cell in the report was green or yellow. But today this is important.' (Ms A, Senior Process Executive)

The interview responses suggest that layout and design are important for reports to be perceived as high quality. The contents of each type of report are carefully documented and regulated, and thus management accountants are expected to follow instructions while preparing reports. Accidental errors in reports are noted further and documented for quality management purposes. 
Further, the comment above implies that physical dirty work has linkages to social relations in the workplace. References to dirty work at a social level are made during interactions between management accountants and the staff of the client. Every management accountant in the department communicates with a contact person on the client's side on a regular basis by telephone or email. The client's representatives have discretion over the contents of the management accounting services provided and, consequently, one-off queries and requests made beyond standard reporting process may cause troubles for management accountants. In a hierarchical relationship, a management accountant has limited ability to resist the actions of the client company's employees, as the excerpt below shows:

'I work with a client that is very knowledgeable and has a million new ideas per minute. She is changing reports all the time - sometimes, five minutes before sending the final report, she changes some important line. Sometimes it irritates me, because I do not have peace and quiet to finish a report, because she is writing and calling at the most critical moments. But she is a client [...]' (Mr D, Management Accounting Specialist)

This comment suggests that ambivalence characterises the work of management accountants in the department. Reporting procedures seem to be in a constant state of flux because of changes in the client's personnel, aspirations or organisational structures, resulting in the feeling of short termism among management accountants. At an individual level, the reliance on the client's demands is reinforced by the department's policy, according to which feedback and evaluation by the client influence performance appraisals and promotions of the management accountants.

The prevalence of dirty work in the management accounting department also has moral underpinnings. Management accountants realise that the outsourcing arrangement is linked to rationalisation on the part of the client company and should bring notable cost savings and efficiency improvements, at least through the means of labour arbitrage. However, they also tend to feel that they are poaching accounting jobs from the client. Such experiences are inevitable since the relationship between the department and the client is dynamic. Continuous migration of projects leads to situations in which numerous management accounting processes are transferred to the premises of 
Outco. As a result, occasionally, management accountants encounter resistance to change among their colleagues in the client company. An interviewee from the managerial level of the department described recurring situations in which employees faced suspicion and reservation:

'Depends on the level of management. Senior management is focused on strategies, they realise, so there is no sentiment. But at the lower level, for example controllers or business analytics [in the client company], they are worried that they will lose their job and they are not very happy with transferring processes to [Outco].' (Mr T, Manager)

It is noteworthy that the moral dirt portrays the shared services sector as dubious, while physical and social stigmas have linkages to individual considerations. It can be argued that in the study's context, the physical distance between the delivery centre and the client's premises, to gain clear wage arbitrage, reinforces the dubiousness of the arrangement.

In summary, dirty work seems to be present in the department both in reporting and unspecified ad hoc tasks. The employees' readiness to talk about the dirty features indicates that management accountants working in the department recognise the 'unusual' elements of their work.

\subsection{Constructing occupational esteem through refocusing strategy}

According to Ashforth and Kreiner (1999, p. 423), people in dirty occupations may employ the strategy of refocusing, where the focus is moved from the dirty features of work to those that do not carry a stigma.

The findings suggest that the process of refocusing on non-stigmatised, positive features starts with recruitment and training. A completed or on-going academic degree is a prerequisite for becoming a management accountant, but specialisation in accounting or any other business-related field is not necessary. Employees seem to appreciate the low threshold to entering the occupation and the opportunities for development available to people with little experience in accounting. The sampled interviewees included management accountants with degrees in veterinary science or political relations. Accordingly, the most valued characteristics of a management accountant are a 
genuine interest in information technology and a command of business English. Moreover, the most sought-after skills in management accounting are analytical and competence in handling spreadsheets. The analytical skills do not require interpretation of accounting measures or business operations but an understanding of the processes and procedures of accounting systems.

The department pays considerable attention to training to equip its employees with the skills needed in the context of a shared services centre. According to internal documents, the aim of the training designed for newcomers is 'to allow comprehensive, quick and efficient learning processes to educate people towards becoming accountants in a limited time period'. During their training, accountants learn soft skills, company culture and the technological tools to be used in the delivery centre. In addition to in-house training, management accountants are expected to earn the ACCA Diploma (exams F1-F3) or CIMA Certificate (exams C01 and C02). However, the decision to embark on a career in shared services appears to be an outcome of coincidence rather than planning, as illustrated by the following interview excerpt:

'My first job in [a manufacturing company] as an accountant was extremely boring-no challenges, no innovations. I was like a direct worker at a factory. So I was looking for something different. I had colleagues in Outco who recommended me to this company, so I sent my CV. Now I have been here for four years, and I must admit that work here is very interesting. If you need a change, you can switch departments. And you always learn something new. I face many challenges in management accounting services, it is true, but I am learning all the time. I have learned new IT tools and analysis. I like collaborating with the international client; it gives me an opportunity to improve my language skills.' (Mr R, Process Manager)

It appears that refocusing also occurs through selective comparisons, which often have social undertones. As the quotation above implies, accounting tasks in an 'ordinary' industry are perceived as dull and one-sided compared to those in the department, where the nature of the job is increasingly dynamic. It is also noteworthy that the department has a truly international environment, in which management accounting is performed across different geographical areas and time zones. As typical newcomers are recent graduates without any notable employment experience, permanent contracts of employment, standardised job descriptions and a team-based organisation of work make the job 
opportunities in the department seem attractive. The following interview excerpt exemplifies how refocusing through comparison to other occupational roles is used to create esteem:

'I am not interested in real accounting and auditing. I know how to record transactions, but I am afraid of responsibility [...] Here I am also responsible for what I do, but not materially. I deal with data, not money, as in the case of accounting. Any errors I make in management accounting will not result in errors in financial statements [...] Here I only download data from the system and elaborate on it [...] I want to stay here in management accounting, but I would prefer to move to process transfers from the client.' (Ms M, Business Analyst)

This response illustrates that management accountants do not face any ambivalence with regard to their roles. Moreover, it appears that the management accounting department enjoys the best reputation in the implicit ranking of departments, as it offers the most advanced services to the client. This is confirmed by the delivery centre's HR representative:

'Management accounting is a rather prestigious department here, lots of people from other departments see them as higher level. They would like to work there, but they are slightly afraid, as you have to have analytical skills and high IT skills.' (Ms K, HR Manager)

The strategy of refocusing also occurs via prospects of career progress. The department offers vacancies for people with varying intentions and characteristics; thus, management accountants can specialise in certain tasks, which include technical or human elements. Further, it appears that a role transfer is a relatively straightforward procedure, as noted in the interview excerpt below:

'Researcher: What about your personal assessment?

Employee: I prepare my personal assessment, containing my achieved results, and my clients assess me on a scale of one to ten. Then I discuss this assessment with my team leader and compare the clients' views with mine. I also have personal targets for development and training [...] You can have four kinds of results - standard, better than required, less than required and super. If you have a less than required result, you will not get a bonus for half of the year. Those who receive a super result more than twice will sooner or later be promoted.' (Ms K, Senior Business Analyst)

As the comment above implies, potential career progress is explicitly linked to the performance evaluation system. From the perspective of a management accountant, the criteria for promotion appear to be pellucid, underscoring quality in work and client satisfaction. To achieve career progress, one should hold a position for at least one year, as well as participate in obligatory training that ends 
with a test. An unwritten code among the staff is that, 'you should change a position at every second year', implying that swift rotation is valued. It is noteworthy that the department also provides opportunities for horizontal career progression. There are several accounting teams, and each team has a different view on the operations of the delivery centre and the client. Instructions for each task make it easier for a management accountant to transfer between tasks.

\subsection{Modifying the meaning of work through reframing strategy}

While the refocusing strategy overlooks the possibly dirty features of the work, the reframing strategy negates the dirty work by attaching new, positive meanings and values to the work (Asforth and Kreiner, 1999, p. 422). This is in line with the insights of Hughes (1958, p. 45-46), according to whom stigmatised occupations are prone to employing 'collective pretension' to foster occupational esteem among the people associated with dirty work and outsiders.

The use of reframing strategy is evident in the collected data. Through reframing, an attempt is made to negate the 'unusual' characteristics of the work performed in the department, relating to mechanical accounting processes. One example of this is recognisable in the naming of job titles in the department. The nomenclature designating different positions is extensive. Various job titles are in use, and most of them connote a managerial or at least expert-like status. When new people enter the department, their job title is usually 'process executive' or 'management accounting specialist'. It could be argued that these job titles increasingly disguise the mechanical and largely repetitive nature of the work. The title of 'team manager' is the most attractive, as the team manager is responsible for the distribution of work among the employees and the execution of daily activities. To exemplify, one management accountant from the department was willing to move to a less prestigious department — namely, financial consolidation — in order to be promoted to a team manager. A process manager is responsible for specified accounting processes for the client, including performance measurement and the evaluation of the management accountants. 
In the empirical data, the most visible sign of reframing is in accounts, where the meaning of the work performed in the department is altered to have positive attributes. Ashforth and Kreiner (1999, p. 421) call this phenomenon 'infusing' in which the stigmatised contents are transformed to 'badges of honour'. The application of the reframing strategy involves certain degree of occupational 'uplifting' or even 'upgrading'. In the department, management accountants pay considerable attention to the continuous development of reporting activities, when permitted by standard reporting routines. It can be argued that management accountants have taken active roles in the rationalisation of their job. Cost saving demands by the client and the recently introduced lean programme have spurred management accountants to take initiative:

'Sometimes I find some activities in my work so boring and laborious that I personally look for improvements. Generally, we suggest full automation of reports, if we see it is possible. This is for all of us value added, they have better and faster reports, we do not spend so much time on doing those reports.' (Ms I, Process Manager).

It could be argued that management accountants' new orientation has helped reframe tasks previously labelled as mechanical to involve genuine opportunities for development. Consequently, management accountants are increasingly rationalising tasks that earlier were the main source for their existence in the delivery centre. As a result of such reframing, even somewhat lower ranked management accountants, such as specialists, consider their job to have notable honour, as seen in the interview excerpt below:

'My job is very creative; we have to improve templates and reports all the time. Now we are working on the full automation of reporting and updating of reports in an online environment.' (Ms E, Process Specialist)

One of the outcomes of such rationalisation is that the number of different reporting templates has been reduced. Most importantly, the rationalisation of reporting activities, leading to the automation of reports, has reinforced the client employees' initiative to produce reports. The aim is that client's staff should be able to prepare the needed reports independently, by refreshing the cells in a template. The lean programme serves as a point of reference for the management accountants in the 
rationalisation of their work. The use of time is monitored in the department, and hence employees know somewhat in detail how much time reporting activities take. Through active automation of the accounting processes, management accountants can develop occupational esteem and provide added value to the client in terms of cost savings.

'A single marketing report takes 270 minutes, a managerial report takes one day and smaller reports take 170 minutes each. So, for 12 markets, it takes two days on average. Look, everything is counted very precisely. Sometimes there are some variations, but rarely [...]' (Ms M, Management Accounting Specialist)

'If we notice that some function or element can be a problem, we immediately suggest improvements. For example, recently we suggested extra macros, then the automatic refreshing of files and some extra functions, allowing one to open 100 campaigns at the same time for all markets.' (Ms R, Process Manager)

It can be argued that the reframing affects how management accountants view their work. Evidence of such re-articulation can be seen in one accounting specialist's concise argument that 'management accounting is improving'. This shift from their traditional role would not be possible without the application of advanced technological tools such as specific reporting templates based on online analytical processing.

\subsection{Consequences of reframing: The emergence of liminal work}

While refocusing portrays the original tasks of management accountants as 'doable', reframing attaches increasingly positive meanings to the dirty features of their work. The data indicate that reframing is an essential means through which management accountants create occupational esteem, even prestige, for themselves in the department. To add to the theoretical ideas of Ashforth and Kreiner (1999), reframing demonstrates a transformative potential, as repetitive, simple tasks are seen as opportunities for 'development' and 'improvement'. In addition to obvious linkages to management accounting, accountants increasingly perceive themselves as technical consultants offering standardisation and automation services. 
'Now we actively work in our department for the full automation of reporting. And after that, we will be only responsible for the maintenance of these reports and the introduction of some changes [...] Practically, we become the IT team, preparing templates, changing them, looking for data in different systems, maintaining systems [...] It is no longer management accounting [...] With this automation and improvements, we undercut the branch on which we sit [...]' (Mr T, Manager)

The comment above captures the managerialistic undertones of the consulting function. The client has imposed cost-cutting measures on the provision of management accounting services on a yearly basis. In response, the department introduced a lean programme, including Kaizen and Six Sigma tools, to meet their cost-saving and efficiency improvement targets. Since the accountants take the initiative to develop reporting technologies, they are constructing their sense of ownership and pride in the provision of management accounting services. The interview excerpt below shows this:

'I can make a comparison, because I have worked in business-to-business and there was a pure client-service provider relationship. So you felt that they are clients and you just have to provide the service. But here it is a real partnership. The client asks for my opinions and suggestions. We have nice, good contact. I feel like a consultant, not like a donkey worker doing dirty work for them. Our communication is friendly but very fruitful and professional.' (Ms A, Process Manager)

It could be argued that the negotiation of the meaning of work is taking place within the department, where accountants balance different roles. Management accountants are assuming an active role in struggling against the dirty elements of their work. In the interview responses, employees actively use the verb 'clean' to describe the developments:

'We cleaned the process and it is well organised and there are not many manual activities [...] Now I do not have any other ideas to improve the process [...]' (Ms K, Senior Business Analyst)

'But as I said, firstly we have to clean all processes, then we will start consulting.' (Mr K, Management Accounting Director)

Thus, it appears that tolerance of dirty work is not in line with the latest occupational aspiration of management accountants. They are increasingly removing dirt from accounting processes, which originally formed the core of their occupational role.

One aspect of the new orientation is that accountants attempt to nurture their relationship with the client to nourish the business. This intention is seen in their unprompted analyses of the client's 
accounting processes and 'discovery visits' to the client's premises at different locations to suggest new process transfers, in which the department takes the responsibility of the process. The notion of a transfer seems to be a recurring theme in the interview materials. On-going transfers from the client's office to the delivery centre is a precondition for the department's future growth. When the 'discovered' accounting processes are transferred, it is followed by standardisation and automation initiatives orchestrated by the management accountants. As evidence, an employee described the prevailing logic of transfers as below:

'In this project, cooperation between us and local controllers was extremely important, because they knew local regulations, and they helped us in this. They explained to us what is necessary because of requirements and what they want and we try to implement this knowledge in the project. On the other hand, we know systems like SAP; we know how to do this technically, we have people with high IT skills and we tried to improve and standardise the process [...] But of course, we were aware of the fact that we could face some problems [...] We informed them about possible problems and about the time we need to solve them.' (Mr M, Process Executive)

Acting as technical consultants, accountants need proactivity as well as negotiation and persuasion skills. It appears that as per departmental jargon, the term 'process' actually means 'project'. The large occupational group of process managers can be seen as project managers who take control of the outsourced process and develop it to ensure efficiency improvement and cost saving. The new occupational role has penetrated the management accountants' language. Expressions such as 'this is our role and target', 'the client has the last word', 'client is king', 'we don't have problems, just challenges' and 'we are a services company' appear regularly and highlight a departure from the original role of managing routine reporting. Since standardisation and automation involve a certain simplification in reporting activities and in the form of the reports, accounting processes undergo an evolutionary development in the department.

Three possible routes exist for the evolution of the client's accounting processes in an environment characterised by constant rationalisation. First, an accounting process could be standardised and automated so as to reduce the involvement of manual work. In an ideal case scenario, 
the client's employees should be able to prepare the needed reports independently, by refreshing the cells in ready-made reporting templates. Second, an accounting process could be discontinued if deemed unnecessary. Occasionally, management accountants recognise that reports have been duplicated or that the original justification of certain reports is unknown. Third, an accounting process could be transferred from the department to Outco's delivery centre in India, where additional labour arbitrage exists. Processes considered as stable and mature, in respect of progress in standardisation, may be good candidates for being transferred to India. This opinion is reflected in the interview excerpt below:

'My team now has fifteen people; at first there were 24 people. The decrease is due to two elements. The first is the transfer of simple, standard tasks and activities, mainly standard reporting, to Outco in India. In simple standard reporting, you only need to refresh the data and pivots with a click. This is something normal, because we migrate standardised processes and activities to India all the time. The second element is that we implement lean. We look closer at processes, eliminate inefficiency, losses and manage to automate our own processes [...] People are usually not fired but are assigned other tasks.' (Ms K, Team Manager)

At an individual level, reframing the service of reporting as technical consulting has shown concrete results in the department. Accountants are increasingly moved to teams where accounting processes are yet to be 'cleaned'. This is somewhat understandable since the consulting orientation leads to situations in which the client's controller independently produces a report from a reporting solution maintained by Outco's accountant. In the excerpts below, employees describe their typical work days in an environment in which cleaning accounting processes is a primary interest:

'I start my day reading emails, to check if there are some new problems or request of my client. Then sometimes I have to contact also my clients to clear some issues and inform him/her how long it will take to realise the request.' (Mr M, Process Manager)

'I start at 8 o'clock. First I check mails, if there are some questions from clients. Because we support all markets and business, there are many questions about reports: why macro is not working, why there are such numbers, or why something else does not work. Sometimes I spend all my day answering those questions and solving those problems. Then if it is the day of reporting, I prepare reports. Otherwise, I work on improvements. For example, I create a new macro, or correct existing one, or change structure of report, because there are changes in the structure of [the client].' (Ms M, Management Accounting Specialist) 
With automation, employees' job contentment is more open-ended as their tasks include responding to unspecified technical matters. Nevertheless, some business-oriented aspirations exist among the accounting workforce. A few management accountants are willing to extend their role beyond the technical matters. In preparing reports, some accountants have managed to develop an 'eye' for numbers - a skill that can be useful in the interpretation of results. This finding illustrates that accountants consider the potential business orientation as valuable, although technical consulting also represents an improvement from standard reporting. One accountant acknowledges that the potential for business orientation requires considerable championing:

'I like management accounting, because in comparison with other departments in Outco, we have an interesting job. Frankly speaking, I would like not only to prepare reports but also to analyse them and suggest managerial solutions to [the client]. I know that in Outco there is a project team working on new solutions and services for the clients, so maybe sooner or later we will do analysis. But I try to do it now. I suggest some changes to the client, I do not analyse information, but I suggest they add new elements to reports to improve their analytics.' (Mr D, Management Accounting Specialist)

The comment above implies that management accountants are not fully content with their new orientation, as it still lacks attributes, such as contribution to decision making and linkage to business management (Morales and Lambert, 2013). It can be also argued that the shift from routine reporting to offering standardisation and automation services may lead to a certain uncertainty among management accountants with regard to their future.

'Then we have lean project and Kaizen, but for me it is difficult to implement. I was working for project, there is a lot of ad hoc work, so we cannot standardise it [...]' (Mr R, Process Manager)

The metaphor of liminal work may characterise the work of management accountants involved in the new occupational orientation (see Czarniawska and Mazza, 2003). In liminal work, management accountants separate themselves from repetitive tasks and concentrate on the technological accomplishment of reporting. They use the term 'ad hoc' to refer to activities, which are not standardised. It may be that these ad hoc tasks appear as 'havens', which cannot be covered by the 
most obvious standardisation and automation initiatives. As automation endeavours affect the accounting workforce needed for providing accounting services, standardisation and automation may appear as an ambiguous problem for accountants.

'Yes, I would call it mature, now we concentrate only on checking if the numbers are correct, it is also very highly automatized, but there are always places for improvement [...]' (Mr M, Process Executive)

This excerpt illustrates that a technical orientation requires a certain degree of creative and analytical skills compared to the previous orientation in which job designs were clearly defined and regulated. In addition to the uncertainty, the new orientation may cause feelings of instability among management accountants as there are necessarily no limits to the degree of automation. However, the comment above implies that the degree of automation is in 'eye of beholder', and thus, a subjective perception. Thus, it appears that a management accountant has certain influence on the direction of automation as long it fulfils the client's expectations:

'Hard to say, now it [the level of maturity] is quite good. But nobody knows what changes they will plan to introduce in the business, in the markets and products that will need complete reorganisation of my reports [...]' (Ms I, Process Manager)

Overall, the responses suggest that the reframing strategy is linked to the transformation of work in which the meaning of being an accountant in the department is renegotiated. Thus, accountants become involved in liminal work in which the work of accounting is transferred towards unspecified ends by means of standardisation and automation.

\section{Discussion}

The purpose of this study was to improve understanding of the work of management accountants in the context of a shared services centre. Since literature typically focus on the more prestigious elements of a management accountant's occupation (Morales and Lambert, 2013, p. 229), this article focused on individuals who make their living doing less prestigious accounting tasks. This is an 
important point of departure as the vast majority of the accounting workforce has traditionally been classified as 'clerical' instead of 'professional' (Cooper and Taylor, 2000, p. 555). Moreover, most businesses prefer to move business support functions to service centres where activities are processed as efficiently as possible (Howcroft and Richardson, 2012). In line with these insights, there have been calls to enhance critical discourse on practices around shared services centres (Seal and Herbert, 2013; Oliveira and Clegg, 2015) and focus on the employees' perspective (Lindvall and Iveroth, 2011; Herbert and Seal, 2012).

To aid the interpretations of the data, this study uses the concept of dirty work as a theoretical perspective (Ashforth and Kreiner, 1999; Hughes, 1958). The concept assumes that, in society, some tasks within an occupation are considered tainted or shameful, which others may attempt to avoid. Insights from practice theory have been incorporated in our analysis since work practices increasingly depend on practices' relatedness to strategies, techniques and clients (Ahrens and Chapman, 2007, p. 23). According to Stern (2003, p. 186), a practice is something people do on a regular basis. Among the management accountants interviewed, feelings and experiences with regard to dirty work are common. The physical dirtiness is an increasingly individual and, therefore, subjective experience. The work of a management accountant could be described as repetitive, with reporting and ad hoc tasks being performed under strict conditions. The social dirtiness emerges in encounters where the client exerts an influence over the relationship. The work may also appear isolated as contacts in the client company are located in another country, and the interaction that takes place is largely faceless. The moral dirtiness is linked to the logic of shared services sector and outsourcing business. The rationale of the relationship is largely based on a wage arbitrage, and thus the advantages stemming from the relationship are more quantitative than qualitative in nature. Thus, the paper's first research question focused on 'How do management accountants create a sense of occupational esteem working in a shared services centre?' 
Two types of strategies for creating occupational esteem have been identified from the empirical data provided by management accountants: refocusing and reframing. In the refocusing strategy, employees focus on non-stigmatised features of their work. As a consequence, negative attributes are mitigated as they are placed against the backdrop of a collection of positive attributes. Management accountants appeared to be thankful for the opportunities they have been given by the department. A relatively low barrier of entry to the job, extensive training as well as horizontal and vertical career progression are of importance. Accountants employ selective comparisons, wherein the services centre is portrayed as having a dynamic, sociable and international environment compared to the jobs in other industries. Consequently, independent and somewhat stable tasks characterising the work of a management accountant in other industries are interpreted in a negative light. Thus, it could be argued that the refocusing strategy in particular has linkages to a strong workplace culture and is often observed in circumstances of dirty work (Ashforth and Kreiner, 1999). Moreover, it appears that dirty work is increasingly difficult to grasp, as the dirty features are neutralised when they 'are integrated into the whole' socio-technical system in an organisation (Hughes, 1958, p. 52). In all, the use of the refocusing strategy complements previous research on motivations to engage in shared services careers (Rothwell et al., 2011).

In the reframing strategy, positive meanings are attached to the work of management accountants. The reframing strategy has linkages to renegotiation of meaning and value related to accounting in the context of the shared services centre. For instance, developing reporting processes towards standardisation and automation are perceived as sources of occupational honour in the department. To complement the theoretical view of Ashforth and Kreiner (1999), the emergence of the reframing strategy in the workplace may have transformative potential beyond the re-articulation of meaning. The recently introduced lean programme in the studied organisation encouraged management accountants to purposefully rationalise and streamline their job designs. As a result of reframing, the work of management accountants revolves around standardisation of diverse reporting 
templates and developing them toward automation. Among management accountants, management accounting performed in the department is increasingly perceived as technical consulting in which accountants attempt to migrate the client's laborious accounting processes and 'clean' them through standardisation and automation. Thus, the reframing strategy illustrates how management accountants adopt an active stance towards certain features of work, which could be perceived as dirty. This strategy is guided by managerial objectives, aimed at cost reductions in the provision of management accounting services.

Although a growing number of accounting studies have examined shared services centres (Seal and Herbert, 2013; Lindvall and Iveroth, 2011), they mostly focus on the more 'positive' side of the relationship. For instance, Herbert and Seal (2012) refer to management accountants who have maintained favourable organisational positions despite the arrangement. On the other hand, this study analysed management accountants who are 'programmed to receive' and perform the client's accounting tasks. In this regard, the paper's second research question focused on 'How does the technology-focused nature of management accounting work in a shared services centre affect the occupational esteem of management accountants?'

Our analysis suggests that in the department, management accountants are moving from generating reports to offering standardised reporting solutions. This orientation towards technical consulting is pervasive, and accountants justify their value to the client by developing efficient standardised reporting solutions. It can be argued that in the department, management accountants perform liminal work (see Czarniawska and Mazza, 2003; Kornberger et al., 2011) as accounting processes are standardised and automated, or eliminated if deemed unnecessary. Through liminal work, management accountants separate themselves from the previous occupational orientation, associated with the production of accounting reports, and adopt a technical consulting orientation. This kind of liminal work can be characterised as uncertain and open-ended compared to the earlier work environment, which was more stable and defined. Outco with its numerous delivery centres 
around the world, can move some accounting processes to India, once the process is stable enough. In light of this, a distant delivery centre in India seems to be the 'last resort' for an accounting process. The findings of the study confirm the observation by Seal and Herbert $(2013$, p. 202) that work in shared services centres is undertaken by 'technical rather than professional workers', and the work is done by a decreasing number of employees - in case new processes have not been selected to migrate.

\section{Conclusions}

The study analysed the work of management accountants in the department of a shared services centre, which provides management accounting services to its client. The study contributes to the extant knowledge in the following ways.

First, the study's findings improve understanding of the linkages between management accountants' occupational esteem and dirty work. The study by Morales and Lambert (2013) illustrated how management accountants differentiated between dirty and clean tasks with regard to their occupational aspiration. Unclean tasks were clearly against their desired occupational orientation, while polluted tasks were duties, which eventually resulted in demeaning experiences for them. The study contributes to this discussion by offering the metaphor of liminal work to characterise the features of the transition from dirty to increasingly clean work. Liminal work can be described as an ambiguous and uncertain phase in which management accountants proceed to new occupational areas, which represent a clear departure from their previous, original occupational orientation. In their study, Morales and Lambert (2013) argue that the transition between dirty and clean work could be a painful experience for accountants, as new polluted, or at least unclear, encounters and situations may emerge as a result. In line with this insight, the study's findings suggest that the new occupational orientation, that we called technical consulting, does not necessarily indicate a positive development for management accountants in the department. Because of standardisation and automation endeavours, and relocation of work to India, management accountants may face occupational 
'unravelling' as their original occupational core has been deskilled (see Cooper and Taylor, 2000). Thus, this study underlines 'the complexity of seemingly mundane everyday accounting' (Ahrens, 2009, p. 31). Contrary to the research setting of Morales and Lambert (2013), in the department examined, the cleaning of dirty features from accounting processes was initiated by the centre's management in order to achieve efficiency gains.

Second, our study contributes to the nascent field of study, which elucidates the effects of standardisation and automation from the perspective of accountants (see Cooper and Taylor, 2000). It has been argued that digitisation affects 'the form, substance and provenience' of accounting information (Bhimani, 2003, p. 1). In parallel, many activities once performed within organisations, are today provided by external services providers (Bhimani and Willcocks, 2014, p. 482). The study illustrates how accounting activities have been reduced to separate accounting processes, framed by esoteric technical attributes. As a result, the actual work of management accountants in a shared services centre is increasingly difficult to grasp as the work is associated with development of technical solutions. Thus, this study demonstrates how standardisation and automation, as a part of digitisation, affect the conception what is considered accounting knowledge (see Bhimani and Willcocks, 2014, p. 482). To add to the findings by Seal and Herbert (2013, p. 200), the study argues, however, that social, interpersonal and analytical skills are still important, despite the specialisation of work, as accountants constantly negotiate with clients, analyse their processes and respond to openended queries. In light of this, accounting is not an abstract and static category but an active process (see Geiger, 2009, p. 131). Broadly, the study shows how shared services centres are moving from handling transactional activities to offering standardisation and automation services, which are based on effective and innovative use of information technology (Bhimani and Willcocks, 2014).

As with every study, this one too has its limitations. It is possible that the features of the research context are unique and may not be found in other settings. It is also noteworthy that the study has been conducted in an outsourcing company where the chief concern is commercial success. 
Nevertheless, we believe that the findings have features that are analogous to development possibly taking place in shared services centres operating in the public sector. Finally, although we consider our access to Outco as good, we could not ensure that the company's managers were unbiased in nominating employees for interviewees.

Nevertheless, it is important to highlight that the study's purpose is not to condemn shared services centres or accountants willing to engage with them. Shared services may still provide unique opportunities for accountants to improve their understanding of technical accounting processes. Future studies could analyse accountants' experience of liminal work from a processual perspective, or how the new occupational orientation affects shared services centres' surveillance and monitoring mechanisms.

\section{Appendix}

Details of the interviews

\begin{tabular}{|l|l|l|l|l|}
\hline Date & Firm & Interviewee(s) & $\begin{array}{l}\text { Duration } \\
\text { (mins) }\end{array}$ & $\begin{array}{l}\text { Educational } \\
\text { background }\end{array}$ \\
\hline January 2016 & $\begin{array}{l}\text { Outco, } \\
\text { Client }\end{array}$ & $\begin{array}{l}\text { Workshop: Led by the Management } \\
\text { Accounting Director with the Managers, } \\
\text { Team and Process Managers, Specialists and } \\
\text { the client's Partnership Development } \\
\text { Director of Finance Operations (10 people) }\end{array}$ & 153 & N/A \\
\hline January 2016 & Outco & Process Manager (Ms I) & 30 & $\begin{array}{l}\text { MA in Finance \& } \\
\text { Accounting }\end{array}$ \\
\hline January 2016 & Outco & Process Specialist (Ms E) & $\begin{array}{l}\text { MA in Physics + } \\
\text { ACCA }\end{array}$ \\
\hline January 2016 & Outco & Process Manager (Mr M) & $\begin{array}{l}\text { MA in Business \& } \\
\text { Technology }\end{array}$ \\
\hline January 2016 & Outco & Team Manager (Ms K) & $\begin{array}{l}\text { MA in Geography, } \\
\text { Veterinary + ACCA }\end{array}$ \\
\hline January 2016 & Outco & Process Manager (Mr R) & MA in Management \\
\hline January 2016 & Outco & Management Accounting Director (Mr K) & 41 & $\begin{array}{l}\text { MA in Economics } \\
+ \text { ACCA }\end{array}$ \\
\hline January 2016 & Outco & $\begin{array}{l}\text { Team promotion and advertising costs } \\
\text { control and planning: Process Manager (Mr } \\
\text { R) and two Management Accounting } \\
\text { Specialists }\end{array}$ & 80 & $\begin{array}{l}\text { MA in Finance \& } \\
\text { Accounting; } \\
\text { students of } \\
\text { economics }\end{array}$ \\
\hline February 2016 & Outco & Management Accounting Specialist (Ms M) & 35 & MA in Mathematics \\
\hline February 2016 & Outco & $\begin{array}{l}\text { Senior Process Executive (Ms A) } \\
\text { MA in Finance \& } \\
\text { Accounting }\end{array}$ \\
\hline
\end{tabular}




\begin{tabular}{|c|c|c|c|c|}
\hline February 2016 & Outco & $\begin{array}{l}\text { Two Management Accounting Specialists } \\
\text { (Ms D, Mr D) }\end{array}$ & 130 & $\begin{array}{l}\text { MA in IT \& } \\
\text { Econometrics; MA } \\
\text { in Business \& } \\
\text { Technology }\end{array}$ \\
\hline February 2016 & Outco & Manager (Mr T) & 48 & $\begin{array}{l}\text { MA in Maths + } \\
\text { ACCA }\end{array}$ \\
\hline February 2016 & Outco & Process Manager (Ms A) & 41 & $\begin{array}{l}\text { MA in English } \\
\text { Philology }\end{array}$ \\
\hline February 2016 & Outco & $\begin{array}{l}\text { Team Manager (Ms K) and Process } \\
\text { Executive (Ms K) }\end{array}$ & 80 & $\begin{array}{l}\text { MA in Economics; } \\
\text { MA in Economics }\end{array}$ \\
\hline February 2016 & Outco & Process Executive (Mr M) & 35 & $\begin{array}{l}\text { MA in Political } \\
\text { Relations }\end{array}$ \\
\hline February 2016 & Outco & Manager (Lean) (Mr M) & 60 & $\begin{array}{l}\text { MA in IT \& } \\
\text { Econometrics }\end{array}$ \\
\hline February 2016 & Outco & Process Manager (Ms I) & 43 & MA in Economics \\
\hline February 2016 & Outco & Business Analyst & 45 & $\begin{array}{l}\text { MA in Finance \& } \\
\text { Accounting }\end{array}$ \\
\hline February 2016 & Outco & Senior Business Analyst (Ms K) & 73 & $\begin{array}{l}\text { MA in Finance \& } \\
\text { Accounting }\end{array}$ \\
\hline May 2016 & Client & Junior Controller & 30 & $\begin{array}{l}\text { MA in Finance \& } \\
\text { Accounting }\end{array}$ \\
\hline June 2016 & Client & Senior Controller & 30 & $\begin{array}{l}\text { MA in Finance \& } \\
\text { Accounting }\end{array}$ \\
\hline June 2017 & Outco & Management Accounting Director (Mr K) & 45 & $\begin{array}{l}\text { MA in Economics } \\
+ \text { ACCA }\end{array}$ \\
\hline June 2017 & Client & Financial Planning and Analysis Manager & 27 & $\begin{array}{l}\text { MA in Managerial } \\
\text { Economics }\end{array}$ \\
\hline August 2017 & Outco & $\begin{array}{l}\text { HR Manager (Ms K) and } \\
\text { Management Accounting Director (Mr K) }\end{array}$ & 30 & $\begin{array}{l}\text { MA in Economics; } \\
\text { MA in Economics } \\
+ \text { ACCA }\end{array}$ \\
\hline \multicolumn{5}{|c|}{23 research interviews, $21 \mathrm{~h} 36$ minutes in total } \\
\hline
\end{tabular}

\section{References}

Ahrens, T. (2009), "Everyday accounting practices and intentionality", in Chapman, C.S., Cooper,

D.J. and Miller, P.B. (Eds.), Accounting, Organizations, and Institutions, Oxford University Press, Oxford, pp. 30-47

Ahrens, T. and Chapman, C. S. (2007), "Management accounting as practice", Accounting, Organizations and Society, Vol. 32 No. 1, pp. 1-27.

Akroyd, C. and Maguire, W. (2011), "The roles of management control in a product development setting", Qualitative Research in Accounting and Management, Vol. 8 No. 3, pp. 212-237. 
Ashforth, B. E. and Kreiner, G. E. (1999), “'How can you do it?’: Dirty work and the challenge of constructing a positive identity", Academy of Management Review, Vol. 24 No. 3, pp. 413-434.

Ashforth, B. E., Kreiner, G. E., Clark, M. A. and Fugate, M. (2007), "Normalizing dirty work: Managerial tactics for countering occupational taint”, Academy of Management Journal, Vol. 50 No. 1, pp. 149-174.

Ashforth, B. E. and Kreiner, G. E. (2014), "Dirty Work and Dirtier Work: Differences in Countering Physical, Social, and Moral Stigma", Management and Organization Review, Vol. 10 No. 1, pp. 81-108.

Baran, B. E., Rogelberg, S. G. and Clausen, T. (2016), "Routinized killing of animals: Going beyond dirty work and prestige to understand the well-being of slaughterhouse workers", Organization, Vol. 23 No. 3, pp. 351-369.

Bhimani, A. (2003), "Digitization and accounting change", in Bhimani, A. (Ed.), Management Accounting in the Digital Economy, Oxford University Press, Oxford, pp. 1-12.

Bhimani, A. and Willcocks, L. (2014), “Digitisation, 'big data' and the transformation of accounting information", Accounting and Business Research, Vol. 44 No. 4, pp. 469-490.

Cooper, C. and Taylor, P. (2000), "From Taylorism to Ms Taylor: The transformation of the accounting craft”, Accounting, Organizations and Society, Vol. 25 No. 6, pp. 555-578.

Czarniawska, B. and Mazza, C. (2003), "Consulting as a liminal space”, Human Relations, Vol. 56 No. 3, pp. 267-290.

Geiger, D. (2009), "Revisiting the concept of practice: Toward an argumentative understanding of practicing", Management Learning, Vol. 40 No. 2, pp. 129-144.

Harritz, D. (2016), "Role of management devices in enacting strategy — case study of Shared Service Centre", Journal of Accounting \& Organizational Change, Vol. 12 No. 4, pp. 504-521. 
Herbert, I. P. and Seal, W. B. (2012), "Shared services as a new organisational form: Some implications for management accounting”, The British Accounting Review, Vol. 44 No. 2, pp. 83-97.

Howcroft, D. \& Richardson, H. (2012), “The back office goes global: Exploring connections and contradictions in shared service centres", Work, Employment \& Society, Vol. 26 No. 1, pp. 111127.

Hughes, E.C. (1958), "Work and the self”, in Hughes, E.C. (Ed.), Men and Their Work, The Free Press of Glencoe Collier-Macmillan Limited, London, pp. 42-55.

Jenkins, S. and Delbridge, R. (2016), “Trusted to deceive: A case study of 'strategic deception' and the normalization of lying at work", Organization Studies, Vol. 38 No. 1, pp. 53-76.

Kornberger, M., Justesen, L. and Mouritsen, J. (2011), “'When you make manager, we put a big mountain in front of you': An ethnography of managers in a Big 4 accounting firm", Accounting, Organizations and Society, Vol. 36 No. 8, pp. 514-533.

Kreiner, G. E., Ashforth, B. E. and Sluss, D. M. (2006), "Identity dynamics in occupational dirty work: Integrating social identity and system justification perspectives”, Organization Science, Vol. 17 No. 5, pp. 619-636.

Kunda, G. (1992), Engineering Culture. Temple University Press, Philadelphia.

Lindvall, J. and Iveroth, E. (2011), "Creating a global network of shared service centres for accounting”, Journal of Accounting \& Organizational Change, Vol. 7 No. 3, pp. 278-305.

Lukka, K., and Vinnari, E. (2014), "Domain theory and method theory in management accounting research", Accounting, Auditing \& Accountability Journal, Vol. 27 No. 8, pp. 1308-1338.

Morales, J. and Lambert, C. (2013), "Dirty work and the construction of identity. An ethnographic study of management accounting practices", Accounting, Organizations and Society, Vol. 38 No. 3, pp. 228-244. 
Oliveira, J. and Clegg, S. (2015), "Paradoxical puzzles of control and circuits of power", Qualitative Research in Accounting \& Management, Vol. 12 No. 4, pp. 425-451.

Raudla, R. and Tammel, K. (2015), "Creating shared service centres for public sector accounting", Accounting, Auditing \& Accountability Journal, Vol. 28 No. 2, pp. 158-179.

Rothwell, A. T., Herbert, I. P. and Seal, W. (2011), "Shared service centers and professional employability", Journal of Vocational Behavior, Vol. 79 No. 1, pp. 241-252.

Scapens, R. W. (1990), "Researching management accounting practice: the role of case study methods", The British Accounting Review, Vol. 22 No. 3, pp. 259-281.

Seal, W. and Herbert, I. (2013), "Shared service centres and the role of the finance function: Advancing the Iron Cage?” Journal of Accounting \& Organizational Change, Vol. 9 No. 2, pp. $188-205$

Stern, D. (2003), "The practical turn “, in Turner, S.P. and Roth, P.A. (Eds.), The Blackwell Guide to the Philosophy of the Social Sciences, Blackwell, Malden, pp. 185-206.

Sturdy, A., Schwarz, M., and Spicer, A. (2006), “Guess who's coming to dinner? Structures and uses of liminality in strategic management consultancy", Human Relations, Vol. 59 No. 7, pp. 929960.

Whittington, R. (2011), “The practice turn in organization research: Towards a disciplined transdisciplinarity", Accounting, Organizations and Society, Vol. 36 No. 3, pp. 183-186. 
